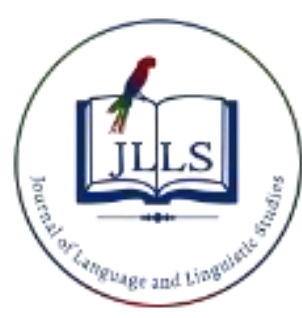

ISSN: $1305-578 \mathrm{X}$

Journal of Language and Linguistic Studies, 16(2), 864-882; 2020

\title{
The effectiveness of L1 use in promoting oral production in L2 across different proficiency levels
}

\author{
Muhammet Yaşar Yüzlü a 1 (iD), Derin Atay b (D) \\ ${ }^{a}$ Bahcesehir University, Istanbul,Turkey \\ ${ }^{b}$ Bahcesehir University, Istanbul,Turkey
}

\section{APA Citation:}

Yüzlü, M.Y., \& Atay, D. (2020). The effectiveness of L1 use in promoting oral production in L2 across different proficiency levels. Journal of Language and Linguistic Studies, 16(2), 864-882.

Submission Date: 23/01/2020

Acceptance Date: 18/03/2020

\begin{abstract}
The current study examines the impact of L1 use on EFL learners' L2 speaking skills as well as their perceptions of L1 use in fostering oral production in L2. The study was conducted for 10 weeks with 60 low intermediate and the high intermediate students at a high school of science in Turkey in 2018-2019 spring term. In each group, half of the students were designated as the experimental group and the other half as the control group. The experimental groups in each level group were exposed to a 10-week (40 hours of teaching) of L1 use in order to promote speaking skills in L2 while the control groups were taught through communicative language approach. In the study, the explanatory sequential mixed methods design was utilized. The analysis of a Paired-Sample t-test indicated that L1 use played a pivotal role in ameliorating students' L2 speaking skills. Semi-structured interviews revealed that students favoured L1 use through which they could attenuate cognitive load and experience stress-free classroom environment in order to improve speaking skills in L2. Lastly, the students exposed to judicious and systematic L1 use outperformed the students exposed to only L2 at low intermediate and high intermediate level as regards boosting oral production in L2 and developing students' positive perception of L2.Pedagogical implications are discussed.
\end{abstract}

(C) 2020 JLLS and the Authors - Published by JLLS.

Keywords: L1 use; oral production in L2; students' perception of L2

\section{Introduction}

The view of utilizing mother tongue (L1 henceforth) to teach the second language (hereafter L2) in classrooms has remained a controversial topic among researchers and teachers (Hall \& Cook, 2014). Some linguists (Atkinson, 1987; Brooks \& Donato, 1994; Cook, 2001; Storch \& Wigglesworth, 2003) claim that the mother tongue presents benefits for a lot of learners as the strategies learners opt for learning are closely associated with mother tongue. However, some linguists (Howatt \& Widdowson,

\footnotetext{
${ }^{1}$ Corresponding author. Tel.: +90 3723150314

E-mail address: myyuzlu@ @otmail.com
} 
2004; Turnbull \& Arnett, 2002; Scott \& de la Fuente, 2008; Littlewood \& Yu, 2009) contend that utilizing the mother tongue in the classroom is likely to impede second language learning. As such, it is of significance for learners to be immersed in L2 only. By the same token, Krashen (1981) suggests that L2 should be taught and learnt by means of second language only and the mother tongue should be expelled during this process based upon his hypothesis of 'comprehensible input'. Likewise, Krashen posits that students must have a significant quantity of exposure of L2 input as long as they desire to improve L2 proficiency inasmuch as utilizing L1 in the classroom makes students deprived of that valuable input. On the other hand, Turnbull (2001) argues that the L2 use does not necessarily imply that it is detrimental for the teacher to utilize the L1. Classroom-based research has shown that teachers shuttle between the languages by utilizing the L1 and the L2 in foreign language (FL henceforth) classrooms (Chang, 2009; Ferguson, 2003) even though FL education has promoted the absolute use of the L2 (Savignon, 1983). Because of the fact that teacher code switching is commonplace in FL contexts, a number of researchers (Swain \& Lapkin, 2000; Turnbull, 2001) have re-examined the L2-only position. The common point of these researches is that there is a warning against the unbounded use of L1, yet they undergird that L1 could be utilized in a judicious manner in cases which include explicating grammatical points, evaluating what the learners have comprehended, vocabulary building and classroom management. The use of $\mathrm{L} 1$ has been propounded for various pedagogical reasons: to augment L2 comprehension (Turnbull, 2001), to scaffold tasks (Anton \& Dicamilla, 1998), to motivate students (Weschler, 1997), to catalyse the move away from L1 to L2 use (Shamash, 1990), to better negotiate (Swain \& Lapkin, 2000).

\subsection{Literature review}

\subsubsection{L1 Use}

Empirical studies over the last decade (Carson \& Kashihara, 2012; Kovacic \& Kirinic, 2011; Lee, 2016; Mahmoudi \& Amirkhiz, 2011; Mohebbi \& Alavi, 2014; Sampson, 2012; Timor, 2012) dwelling on the use of L1 in FL contexts demonstrate that using L1 is deemed to be an useful resource in order to teach English. Additionally, the positive effect of L1 use on FL learning and teaching has been indicated in various studies (Cook, 2010; Nation, 2003; Norman, 2008; Park, 2013; Weschler, 1997). In this regard, the techniques such as sandwich technique including L1 (Butzkamm \& Caldwell, 2009) are intended to enrich existing methodologies. "Bringing the L1 back from exile may lead not only to the improvement of existing teaching methods but also to innovations in methodology" (Cook, 2001, p. 419).

Proponents of L1 use believe that activities involving L1, as long as properly designed, may enhance accuracy and augment receptive - i.e., reading and listening and productive skills - i.e., writing and speaking (Shouyuan \& Xingwei, 2003; Tucker, 1999). It is seen that L1 use has predominantly been integrated into L2 writing (Bruen \& Kelly; 2017; Kaplan, 1966; Qi, 1998; Storch \& Wigglesworth, 2003; Uzawa \& Cummings, 1989; Wang \& Wen, 2002) and reading skills (Anderson, 1991; Block 1986; Kern, 1994; Larsen-Freeman \& Anderson, 2011; O'Malley \& Chamot, 1990; Richards \& Rodgers, 2014; Upton, 1997), whereas the studies dwelling on L1 use in L2 listening (Edstrom, 2006) and L2 speaking are scant.

As the focus moved from reading and writing to listening and speaking with the advent of direct method, audio-lingual approach and communicative approach, L1 was regarded as a factor to be discarded. Yet, there have been some studies focusing on strategies including L1 use so as to elicit oral participation.

Few numbers of studies were carried out in order to investigate impact of L1 use on L2 oral production (Bergsleighner, 2002; Cipriani, 2001). Scott and de la Fuente (2008) additionally highlight that L1 use for the tasks in their study is of help to reduce the cognitive overload. 
In a nutshell, the endeavor to expel L1 in FL contexts may engender waste of time and agony instead of clarifying a language item in which a noncomplex translation would suffice. Atkinson (1993) also states " For many learners (in particular adults and teenagers), occasional use of the L1 gives them the opportunity to show that they are intelligent, sophisticated people " (p.13), which has the potential to yield a positive impact by inhibiting possible frustration learners might experience in FL contexts. Using L1 in a structured and efficient way comes into play at this stage. How to implement L1 use successfully is shown in the following section.

\subsubsection{How to use L1}

Knowing how to use L1 and its strategies which will benefit the learning and teaching process is of significance. To illustrate, L1 use can be helpful so as to make students relax, thus overcoming tense moments and contributing to affective dimension of the learning context. Butzkamm and Caldwell (2009) also indicate that a few humorous utterances may help ease classroom management and keep the lesson on course. Thus, L1 use may reduce the language anxiety. Additionally, discussion in L1 of difficulty areas may play a motivating role for students. Weschler (1997) points out that strategies should be shown in order to eliminate difficulties provided that the class has difficulty in communicating. To exemplify, "I am sorry, I don't know the answer," or " What do you mean?" are among these strategies. Forbidding L1 can be troublesome without these strategies. Thanks to L1, major differences are to be highlighted between L1 and L2, thus enabling the students to be aware of main grammatical characteristics of L2. Students can realize that some basic utterances can't be directly translated and students can learn these utterances through creative information gap activities.

Moreover, Weschler (1997) proposes utilizing L1 for warm-up activities. Words and/or expressions hard to clarify in L2 are translated better. Further, Atkinson (1993) maintains providing "L1 problem clinics" (p. 18) which are utilized in order to discuss points the students haven't comprehended. By same token, L1 can be used to translate individual words, explain grammar use, and facilitate complex instructions. L1 use also bears the potential to be valuable in consciousness-raising as regards explicating eloquently the differences between L1 and L2 (Benson, 2002). In this regard, using L1 at the optimal level comes into play, which is defined by Turnbull and Dailey-O'Cain (2009) as follows:

Optimal first language use in communicative and immersion second and foreign language classrooms recognizes the benefits of the learner's first language as a cognitive and metacognitive tool, as a strategic organizer, and as a scaffold for language development (p.183).

In addition to L1 use strategies, being aware of the guidelines which Cook (2001) proposes could also be helpful. Cook (2001) outlines four benefits associated with integrating L1 use into FL contexts where only L2 would never provide : a) efficiency in which words and/or expressions hard to comprehend can be explicated more effectively, b) learning in which clarifications provided by L1 ease comprehension, c) naturalness in which teachers might form bonds with the students and satisfy their needs more easily in the class and out of the class when compared to only L2 instruction, d) external relevance in which students equipped with L1 and L2 skills could employ both of the languages, ending up being enviable in their future careers. Cook emphasizes that teachers cognizant of these benefits are to ease learning process by integrating L1 judiciously into FL contexts in a manner that only-L2 instruction would not. Cook (2001) accordingly states that there are also methods such as the New Concurrent Method, Community Language Learning and Dodson's Bilingual Method, all of which favour utilizing both L1 and L2 in FL contexts.

There have been studies examining L1 use in EFL settings both in Turkey and all around the world. The research about L1 use generally revolves around two themes: attitudes towards L1 use (Galali \& Cinkara, 2017; Celik \& Aydın, 2018; Tuncay, 2014, Wach \& Monroy, 2019) and patterns and/or functions of L1 use (Grim, 2010; Sali, 2014; Celik \& Aydın, 2018; Timuçin \& Baytar, 2015; Pavon 
Vázquez \& Ramos Ordóñez, 2018). Additionally, patterns have been investigated based on proficiency levels in some studies (Grim, 2010; Thompson, 2006) which aim to determine the pattern of L1 use and support the prevalent use of translation at higher proficiency levels. Likewise, there are studies demonstrating the similar patterns of use at initial levels of proficiency. Macaro's study (2001), for example, reveals that the explaining vocabulary and grammar, doing translations and conducting managerial processes are among the factors motivating to utilize L1 (pp. 539 - 544). Moreover, Grim (2010) indicates that in addition to translations as well as grammar explanations, widespread L1 use takes place in class management and creating metalinguistic awareness (p. 203). Sali (2014) investigates the functions of L1 use at a procedural level in three Turkish EFL classrooms in a secondary school in Turkey. She reveals that L1 use has three functions which are academic in order to communicate the content of the lesson and managerial in order to regulate classroom interactions and social/cultural in order to focus on rapport construction. Similarly, Boot, Azman and Ismail (2014) examine the L1 use in the EFL reading classroom in a university. They reveal that students perceive L1 use as a functional strategy in their classrooms and it serves such functions as translation of new words, definition and explanation of abstract concepts and also helping each other in group studies.

In addition to functions of L1 use have been shown in some studies (Timuçin \& Baytar, 2015), beliefs and attitudes towards L1 use (De la colina \& Mayo, 2009; Kelly \& Bruen, 2015) is another dimension. Tuncay (2014), in her study including 120 teachers teaching at a state university in Turkey finds out that teachers mostly have negative attitude towards L1 use, particularly towards its use as a communicative tool. On the other hand, the teachers do not believe that L1 has negative effect on L2 acquisition. Yenice (2018) also investigates the students' and teachers' attitude towards L1 use in FL classrooms in Turkey. She finds out that seventh and eighth grade students have positive attitudes towards L1 use as opposed to teachers and her study reveals that L1 use has instructional functions, managerial functions, affective functions and social functions.

Additionally, the role of L1 use in order to boost L2 learning has been investigated. Yu underscores the scaffolding role of $\mathrm{L} 1$ which enables to mediate the cognitive resources and provide feedback in a far more specific way. Celik and Aydin (2018) point out a number of pros and cons with regard to L1 use, responsibilities of teachers as well as expectations of students indicated by previous studies. Pavon Vázquez and Ramos Ordóñez (2018) put forward that L1 use does not seem to have an adverse impact on the learning of content. Wach and Monroy (2019) similarly find out that there is a particular need for learners who have low proficiency in L2 to utilize L1. To summarize, the aforementioned studies generally focus on attitudes and functions of L1 use or the impact of L1 use on reading comprehension and writing tasks. Although scant, aforementioned studies on impact of L1 use in oral production investigate beginner groups, not higher level groups. In this regard, there is a dearth of research focusing upon the impact of L1 use on oral production in L2, particularly at different levels with empirical evidence. To address this gap, current research was conducted.

\subsection{Research questions}

The objective of the present study is to explore the issue of whether the oral production in L2 (English) of EFL learners at low intermediate and high intermediate level is enhanced and how the students' perceptions of L2 change when L1 (Turkish) is allowed. In this regard, the following questions are sought:

1. To what extent has L1 use exerted any significant effect upon the low intermediate students' L2 speaking skills? 
2. To what extent has L1 use exerted any significant effect upon the high intermediate students' L2 speaking skills?

3. What is the effect of the L1 use on students' perceptions of L2 use?

\section{Method}

\subsection{Research Design}

In order to identify the impact of the intervention, the quasi-experimental mixed methods design, which is an embedded quasi-experimental design (Dörnyei, 2007; Johnson, Onwuegbuzie, \& Turner, 2007), was implemented by pursuing an explanatory sequential mixed methods design. As Collins, Onwuegbuzie, and Sutton (2006) indicate, there are four pillars in order to employ a mixed-methods research: participant enrichment, instrument fidelity, treatment integrity, and significance enhancement.

\subsection{Participants \& Setting}

The study was conducted on 120 (78 female and 42 male) students. Each proficiency level ranging from low intermediate to high intermediate consists of 60 students studying in the 2018-2019 spring term in Zonguldak Province, Turkey. Just as the low intermediate experimental group consists of 30 students, so does the control group. This is the case for the high intermediate experimental group and control group. Further, 6 students from low intermediate group and 6 students from high intermediate group were interviewed for the qualitative data. The age of participants is approximately 14 or 15 years old for low intermediate student, while the students aged 16 or 17 comprises the high intermediate level. The students were in the 97 percentile in a high stake test titled LGS, which is carried out in order to select the students to be admitted into prestigious high schools around Turkey. Convenience sampling was used when choosing the participants of the study. Proficiency level of low intermediate students is A2, whereas that of high intermediate students is B2 according to CEFR. Students' proficiency level was determined according to the curriculum they follow at their schools. Low intermediate schools were ninth graders, while high intermediate students were 11 graders.

\subsection{Instruments}

Several instruments were used in the study for research purposes. First of two speaking tests were administered and semi structured interview questions were utilized.

\subsubsection{Speaking Tests}

The standardized tests were utilized to evaluate the students' L2 speaking skill at both low intermediate level (A2- KET Speaking) and the high intermediate level (B2- FCE Speaking). The A2KET Speaking test contained two parts: Part 1 includes short questions and answers between the student and the examiner and in Part 2, the examiner gives the student some information or a card with some ideas for questions. They have to talk with the other candidate and ask or answer questions. B2-FCE speaking test contained four parts. Part 1 includes a conversation between the examiner and each student (spoken questions). Part 2 consists of an individual 'long turn' for each student, with a brief response from the second student (they are given a pair of photographs to talk about). Part 3 includes a two-way conversation between the students where they have to decide something. Part 4 consists of a discussion on topics related to Part 3 (spoken questions).

The students were evaluated based on fluency, accuracy, lexical complexity, grammatical complexity and pronunciation. The score range was between 0 and 25. Speaking skills of the students were evaluated 
by two English teachers. So as to ensure the reliability and the extent of the agreement between the two raters, inter-rater agreement was measured and found to be in perfect agreement (ICC $=.824$ for the pretest and ICC $=.856$ for the post-test).

\subsubsection{Attributional Interview Questions}

The interview includes 3 questions (See Appendix A), which elicit the students' perceptions of L1 use on their success in L2 (English) speaking skill test; also, these questions provide insight into the reasons the students attribute their success to in L2 (English) speaking skill test. Following the post-test, 12 volunteer students were interviewed at the end of the term. While 6 students were from the low intermediate level, 6 students were from high intermediate level. The students who were interviewed from low intermediate level and high intermediate level were selected based on maximum variation sampling. Two high achieving, two medium achieving, and low achieving students were selected. It was the case for each level. The participants whose numbers range from 1 to 6 were from low intermediate. The participants whose numbers range from 7 to 12 belonged to high intermediate level. The purpose was to explore the factors leading to their success. The interview was conducted in Turkish. All interviews were recorded and transcribed by the first author.

\subsection{Data collection procedures}

The students in the experimental group were informed about L1 use and later instructed by employing systematic and judicious L1 use in a face-to-face class during the 10 week intervention, thus the students in the experimental groups were able to use their L1 and L2 with their peers and their teacher during class while carrying out warm up brainstorming (Weschler, 1997), information gap filling activities (Weschler, 1997), communication strategies (Weschler, 1997), L1 problem clinics (Atkinson, 1993), strategic organization (Turnbull \& Dailey-O'Cain, 2009) along with pair work and group work, whereas the students in the control groups got instruction following regular method in that low intermediate and high intermediate control group made use of communicative approach in which only-English medium was applied. In the experiment groups in low intermediate and high intermediate level, language mode of input and output in the classroom could deliberately be switched in accordance with the concept of sandwich technique by the teacher and the students as Butzkamm and Caldwell (2009) indicated. Additionally, in parallel with the communication strategies (Weschler, 1997), the students were provided with help language in which they can see the Turkish equivalent of the classroom language and strategic use of language while asking for explanation, clarification as well as request. For instance, they were allowed to use "What does X(L1) mean in L2 (English)?" or vice versa while communicating and they were requested to build on what they have learnt in order not to have the fallacy that they can resort to L1 without concentrating on the communication in L2. In the same fashion, expressions having been clarified should be utilized viably without recourse to L1. It is crucial for the students to note down the novel expressions in an extra book and learn them in order that they will not need to be given again next time. Likewise, L1 expressions which come from the students also should be noted down and compiled. In doing so, the teacher can persist in utilizing L2 phrases (Butzkamm \& Caldwell, 2009).

\subsection{Data analysis}

The data obtained from the speaking pre- and post-tests were analyzed by means of quantitative methods. The participants' scores were compared by using the Statistical Package for the Social Sciences (SPSS) 23.0 within each level of proficiency. To determine whether parametric tests were appropriate, all variables were tested for their normality of distribution by using the KolmogorovSmirnov test. The significance level was set at $p=.05$. Since the data were normally distributed based 
on the result of the Kolmogorov-Smirnov test, the parametric test (paired t-test) was used to determine if there were statistically significant differences between the experimental groups and control groups at each level.

So as to implement the quantitative part of the study, the following procedure was pursued. At the beginning, a pre-test was applied to all groups. The experimental and control group students' pre-test means were compared with paired samples $t$ test. After the pre-test and intervention have been implemented, the post-test was applied to all groups and the results were compared.

Afterwards, an in-depth interview method was adopted to collect qualitative data from the students seeing as interviews can 'yield direct quotations from people about their experiences, opinions, feelings and knowledge' (Patton, 2002, p. 4). Additionally, content analysis was employed for the analysis of the data and results were cross-checked for reliability. Content analysis usually pursues a coding process based upon the research questions. Such steps as determining the unit of analysis, categorizing as well as detecting themes from categories constitute the coding process (Kondracki \& Wellman, 2002). Overall inter-coder reliability was $90 \%$. Coding conflicts were resolved through consensus.

\section{Results}

\subsection{The comparison of experimental and control group's L2 Speaking pre-test score at low intermediate and high intermediate level.}

The first statistical analysis was conducted to check the extent to which the groups are equal. Table 1 and Table 2 show the pre-tests scores of the experimental and control groups at low intermediate and high intermediate level respectively.

Table 1. The comparison of low intermediate experimental and control group's L2 Speaking pre-test scores.

\begin{tabular}{ccccccc}
\hline Group & $\mathrm{N}$ & Mean & $\mathrm{SD}$ & $\mathrm{df}$ & $\mathrm{t}$ & $\mathrm{p}$ \\
\hline Experimental & 30 & 16.60 & 2.19 & & & \\
& & & 58 & -.57 & \\
\hline Control & 30 & 16.93 & 2.32 & & \\
\end{tabular}

As shown in Table 1, it is probable to state that there is not a statistically significant difference between the pre-test mean and standard deviation of the experimental group (Mean=16.60; $\mathrm{SD}=2.19$ ) and the pre-test mean and standard deviation of the control group (Mean=16.93; $\mathrm{SD}=2.32$ ). Accordingly, it is possible to argue that low intermediate experimental group and control group are equal based on the pre-test L2 speaking skill scores before the intervention.

Table 2. The comparison of high intermediate experimental and control group's L2 Speaking pre-test scores

\begin{tabular}{ccccccc}
\hline Group & $\mathrm{N}$ & Mean & $\mathrm{SD}$ & $\mathrm{df}$ & $\mathrm{t}$ & $\mathrm{p}$ \\
\hline Experimental & 30 & 19.73 & 0.98 & & & \\
\hline
\end{tabular}




$58 \quad 1.70 \quad 0.94$

$\begin{array}{lll}\text { Control } & 30 & 19.23\end{array}$

As can be seen from the Table 2, it is possible to mention that there is not a statistically significant difference between the pre-test mean and standard deviation of the experimental group (Mean=19.73; $\mathrm{SD}=0.98$ ) and the pre-test mean and standard deviation of the control group (Mean=19.23; $\mathrm{SD}=1.28$ ). Hence, it is probable to state that high intermediate experimental group and control group are equal based on the pre-test L2 speaking scores before the intervention. As the groups' initial language scores are equal, findings for each research question are presented as follows.

The current study examined the impact of L1 use upon oral production in L2 and upon the students' perception of L2 alike. Three research questions were sought. The first two research questions focused on the impact of L1 use on oral production in L2 and the third question aimed to explore the impact of L1 use on students' perceptions of L2.

\subsection{The impact of L1 use upon the low intermediate students' L2 speaking skills}

The first research question investigated whether L1 use exerted any significant effect upon the low intermediate students' L2 speaking skills. To investigate whether there is any statistically significant difference between pre-test and post-test L2 speaking skill scores of low intermediate Turkish EFL learners who are exposed to L1 use to improve oral production in L2 in comparison with Turkish EFL learners who are exposed to traditional method - communicative approach, i.e., English-only. The participants' scores were calculated and analysed. The descriptive statistics of pre- and post-test English skills scores of students has been illustrated in Table 3.

Table 3. The comparison of low intermediate experimental and control group's L2 speaking pre-tests and posttests

\begin{tabular}{|c|c|c|c|c|c|c|c|c|c|c|c|}
\hline \multirow[b]{2}{*}{ Tests } & \multicolumn{6}{|c|}{ Experimental Group } & \multicolumn{5}{|c|}{ Control Group } \\
\hline & & $\mathrm{N}$ & M & $\mathrm{SD}$ & $\mathrm{t}$ & $\mathrm{p}$ & $\mathrm{N}$ & $\mathrm{M}$ & SD & $\mathrm{t}$ & $\mathrm{p}$ \\
\hline & Pretest & 30 & 16.60 & 2.19 & 13.90 & 0.00 & 30 & 16.93 & 2.32 & $10.27^{*}$ & 0.00 \\
\hline $\begin{array}{l}\text { L2 } \\
\text { Skills }\end{array}$ & Posttest & 30 & 22.60 & 1.07 & & & 30 & 19.43 & 1.48 & & \\
\hline
\end{tabular}

$* \mathrm{p}<0.05$

Table 3 displays that there were significant differences between the low intermediate grade experimental group students' L2 speaking skill pre-test scores $(M=16.60 ; \mathrm{SD}=2.19)$ and post-test scores $(\mathrm{M}=22.60 ; \mathrm{SD}=1.07)$ in favour of post-test scores $\left(\mathrm{t}_{(29)}=-13.90 ; \mathrm{p}<0.05\right)$. In a similar fashion, there were significant differences between the control group students' L2 speaking skill scores $(M=16.93$; $\mathrm{SD}=2.32)$ and post-test scores $(\mathrm{M}=19.43 ; \mathrm{SD}=1.48)$ in favour of post-test scores $\left(\mathrm{t}_{(29)}=-10.27 ; \mathrm{p}<0.05\right)$. As the above table indicates, the existing significant value (.000) is smaller than the significance level (.05). In other words, learners' L2 speaking performance in the experimental group was significantly improved after having instruction that included L1 use. Cohen's d value was calculated for effect size 
of this difference between the control group and the experimental group by making use of effect size calculator by Thalheimer and Cook (2002). Cohen's d value was calculated as 2.5 . This value indicates a huge effect. It can be interpreted that L1 use has a huge effect on L2 speaking skill development.

\subsection{The impact of L1 use upon the low intermediate students' L2 speaking skills}

The second research question investigated whether L1 use exerted any significant effect upon the high intermediate students' L2 speaking skills.

In order to find out whether there is any statistically significant difference between pre-test and posttest English skill scores of high intermediate Turkish EFL learners who are predisposed to L1 use to improve oral production in L2 in comparison with Turkish EFL learners who are predisposed to traditional method - communicative approach, i.e., English-only. The participants' scores were calculated and analysed. The descriptive statistics of pre- and post-test English skills scores of students has been illustrated in Table 4 .

Table 4. The comparison of high intermediate experimental and control group's L2 speaking pre-tests and posttests

\begin{tabular}{|c|c|c|c|c|c|c|c|c|c|c|c|}
\hline \multirow{2}{*}{\multicolumn{2}{|c|}{ Tests }} & \multicolumn{4}{|c|}{ Experimental Group } & \multirow[b]{2}{*}{$\mathrm{p}$} & \multirow[b]{2}{*}{$\mathrm{N}$} & \multicolumn{4}{|c|}{ Control Group } \\
\hline & & $\mathrm{N}$ & M & SD & $\mathrm{t}$ & & & M & $\mathrm{SD}$ & $\mathrm{t}$ & $\mathrm{p}$ \\
\hline L2 & Pretest & 30 & 19.73 & 0.98 & $15.6^{*}$ & 0.00 & 30 & 19.23 & 1.28 & $8.0^{*}$ & 0.00 \\
\hline \multirow[t]{2}{*}{ Skills } & Posttest & & & & & & & & & & \\
\hline & & 30 & 23.10 & 0.86 & & & 30 & 21.80 & 0.98 & & \\
\hline
\end{tabular}

$* \mathrm{p}<0.05$

Table 4 shows that there were significant differences between the high intermediate experimental group students' L2 speaking skill pre-test scores $(\mathrm{M}=19.73$; $\mathrm{SD}=0.98)$ and post-test scores $(\mathrm{M}=23.10$; $\mathrm{SD}=0.86)$ in favour of post-test scores $\left(\mathrm{t}_{(29)}=15.6 ; \mathrm{p}<0.05\right)$. Likewise, there were significant differences between the control group students' L2 speaking skill scores $(\mathrm{M}=19.23 ; \mathrm{SD}=1.28)$ and post-test scores $(\mathrm{M}=21.80 ; \mathrm{SD}=0.98)$ in favour of post-test scores $\left(\mathrm{t}_{(29)}=8.0 ; \mathrm{p}<0.05\right)$. Just as the above table demonstrates, the existing significant value (.000) is smaller than the significance level (.05). Put it differently, learners' L2 speaking performance in the experimental group was significantly improved after having instruction that included L1 use.

Cohen's d value was calculated for effect size of this difference between the control group and the experimental group by making use of effect size calculator by Thalheimer and Cook (2002). Cohen's d value was calculated as 1.43 . This value indicates a very large effect. It can be interpreted that L1 use has a very large effect on L2 speaking skill development. 


\subsection{The effect of the L1 use on students' perceptions of L2 use}

The third question aimed to explore the impacts of L1 use on students' perception of L2. Therefore, in order to find the answer to these questions, a semi-structured interview was conducted by the researcher. For this purpose, 12 students were selected and interviewed at the end of the term.

The interview included three questions and it was conducted in the students' mother tongue. All the interviews were recorded, transcribed, and reanalysed thoroughly and what aspects of L1 use in improving oral production in L2 could have created such an impact on the development of L2 speaking skills of the students and on their L2 speaking anxiety level were explored. After the initial analysis, three main themes and twelve subthemes were propagated and second round of analysis reduced the number of sub-dimensions to ten and ultimately to 6 subthemes after the third round of analysis. From the data the following three main themes were induced to understand the impact of L1 use on students' L2 speaking skill: (a) intrapersonal, (b) contextual, (c) interactional function.

\subsubsection{Intrapersonal Function}

Qualitative data indicates that L1 use has an intrapersonal function in that the learners process the input more effectively and easily.

\subsubsection{Easing Cognitive Load}

While concentrating on learning L2 (English), some students stated that they came to realize that they were able to proceed cognitive processes easily, hence making better comprehension possible. Participant 3 states that she is able to flow the lesson without feeling being lost which occurs thanks to L1 practices by stating "I could not follow the lesson from the beginning to the end as I could hardly understand what the teacher was talking. However, I began to ask about the points which were unclear and understand the topics thanks to permission to L1 use. I used to do more and gain less. Now, it has completely changed. Similarly, participant 12 said: "I realized that I initially managed to understand English and then could speak English. It was something which happened for the first time throughout my school years. When I thought again, I understood that I had not even attempted to speak in English since it was too complex". This quote indicates that the student is able to realize oral production in L2 after decoding the complexity which has seemed to be unmanageable.

\subsubsection{Dual Focus}

Intrapersonal dimension also includes paying attention and focusing on the linguistic features. In this respect, the participant 1 said: "I used to regard the English lessons as solely understanding and conveying the messages regardless of the structure". Likewise the participant 7 said: "Being able to put the message into parts are helpful in order to create new ones" As the quotations make clear, L1 use plays a pivotal role in raising the language awareness in addition to message-orientation.

\subsubsection{Contextual Function}

L1 use has also a contextual function in that it creates the comfortable and genuine environment for learning to take place.

\subsubsection{Stress-free}

Some of the students emphasized the contextual impact of L1 use. They had the opportunity to use the knowledge they have already had and build on it. Participant 4, for instance, said: "I had opportunities to improve English by using my Turkish linguistic knowledge. Hearing, reading, writing and speaking Turkish made me feel comfortable". By the same token, participant 10 expressed the enjoyment due to the L1 use occurring for the first time by saying "being unable to understand what 
was happening in the classroom was making me stressful but now I feel I can decipher English thanks to my Turkish knowledge".

Additionally, participant 17 drew attention to the engaging aspect of L1 use during the English classes in her quote as follows:

As I noticed that I was improving my English by using Turkish, I began to participate

in activities and I never experienced the feeling of being lost, which I used to

experience.

\subsubsection{Biculturally-laden embeddedness}

Another aspect highlighted by the students was the cultural elements. Some students expressed that they felt that the lessons incorporated the Turkish and English culture during the English lessons, thereby enhancing their cultural awareness in that the reactions and feelings are sometimes expressed in a similar way and sometimes in a different fashion. To give an example, participants 5 and 8 said respectively:

"L1 use made me notice the cultural similarities and differences in conveying messages about events and I could comprehend the mind-set of Turkish and English culture. I felt to have been informed more about a lot of topics ranging from greetings, food to expressing opinions and discussion skills."

"It was great to notice how we, Turkish people, react to a situation in a similar way to English people. At the same time, L1 use made me regard the language as a cultural component to convey meanings. Sometimes words do not suffice".

Moreover, some students pointed out that L1 use made them perceive the language as a part of the culture. In other words, the language began to be regarded as the expression of lifestyle rather than clustering words in a haphazard way. In this regard, participant 6 stated the cultural aspect of the L1 use by saying "Actually, I began to grasp my own culture and English culture better by analogizing. I realized that I had regarded English as putting words together beforehand. Now I see that knowing a language is also discovering another culture". Similarly, participant 11 also mentioned "speaking English is not just putting the words together but knowing the way English people think, live and communicate in comparison to Turkish. I had not noticed this factor until L1 was used in similar cases".

\subsubsection{Interactional Function}

L1 facilitated the communication by removing the block for comprehension, paving the way for continuous meaningful interactions.

\subsubsection{Unobstructed Communication}

Some students underscored that the focus was on keeping communication. Moreover, they started focusing on conveying message through dual focus both on the message and the form. Participant 3 and 8 respectively accentuated their developed communicative abilities by means of L1 use by saying:

\footnotetext{
"While I was making the dialogues, I began not to be afraid of misunderstanding or better said I was not afraid of being unable to understand thanks to Turkish use. Previous knowledge and explanations and also L1 problem clinics were of great help. Thus, I enjoyed carrying out dialogues without being stuck in somewhere between."

"The lessons were enjoyable because I managed to work out English or maybe understand the secret of the language thanks to Turkish use. I achieved to express my thoughts and feelings without using the stereotype structures and I started to carry on the conversation until I conveyed my thoughts. In the past I used to just feign by using same memorized chunks for the situations."
} 
Furthermore, some students started to participate in the classes as can be deduced from the following quote of participant 2 .

"I used to shy away from dialogues and rarely took part in discussions. L1 use scaffolded my understanding and encouraged me to take part in. I guess it triggered something inside".

Likewise, participant 8 stated that L1 use backed up his communicative skills and he finally managed to talk in L2 by saying "I had lots of fun, and my dream came true. I could speak in English without feeling lost in a strange place. Being able to use Turkish enabled me to decipher English and encouraged me not to be afraid.

\subsubsection{Inquiry-oriented}

Interactional function implies also inquiring and making sense. In this respect, the participant 5 said: "I regarded dialogues or discussions as not just a duty in which memorized structures and chunks would be used but as a meaning-making process by questioning. I started to focus on the message and the form alike. Actually, they were like something to explore". The quotations imply that L1 use has a pivotal role in spurring the inquiry into the language system and the messaged conveyed.

\section{Discussion}

The current study sought to address three research questions. As far as the first research question addressing the impact of L1 use upon the low intermediate students' L2 speaking skills is concerned, the data analysis revealed that students exposed to L1 use outperformed those exposed to only L2 with respect to L2 speaking skill at low intermediate level. Furthermore, it was found out that L1 use had a huge effect on L2 skill development of low intermediate learners, which align with the findings of the studies about beginner level students (Bergsleighner, 2002; Cipriani, 2001).

The findings of the second research question dwelling on the impact of L1 use upon the high intermediate students' L2 speaking skills demonstrated that students exposed to L1 practices outperformed those exposed to only L2 concerning L2 speaking skill at high intermediate level. It resonates with the results posited by Scott and de la Fuente (2008). Moreover, it was found out that L1 use practices had a very large effect on L2 speaking skill of high intermediate learners. Accordingly, it is possible to state that the systematic positive use of L1 augments the oral production in L2. These findings resonate with the fact that Cook (2001) highlights "new avenues are opened for language teaching which involve the active, systematic use of the MT" (p. 418). Additionally, it is probable to suggest redressing the imbalance which emerges due to only L2 use and argue, in a similar way to Dodson (1967) that ignoring L1 as a resource should be re-questioned. Bruner (1983) also uses the phrase Language Acquisition Support System in order to accentuate the scaffolding role of L1 use in aiding students to be engaged in learning process in FL contexts. Furthermore, the fact that L1 use yields better results at the beginning levels (Butzkamm \& Caldwell, 2009) has been borne out by the findings in this study. Likewise, it is not rare for EFL learners to use their L1s as the prior obtained dominant cognitive tools (Vygotsky, 1978).

The findings based upon the qualitative data as regards the third research question revolving around effect of the L1 use on students' perceptions of L2 use revealed that L1 use comprises three dimensions: intrapersonal, contextual and interactional. As for intrapersonal dimension, it is possible to see cognitive effect of L1 use in learner-internal mechanism. In terms of learner-internal mechanism, Ellis (1994) makes the distinction between cognitive and mentalist explanations with respect to L2 acquisition in that cognitive view regards L2 acquisition as being the same as any other type of learning. Yet, a mentalist account focuses on the distinction between competence and performance. Although the logic 
based upon Chomskyan position of permanent availability of implicit learning (Universal Grammar), a plethora of cognitive-interactionist researchers (Long, 1996; Russell \& Spada, 2006) would favour explicit instruction involving conceptually driven processing for L2 learning, particularly as regards accuracy and rate (Ortega, 2014). Accordingly, the increase of gain scores in the experimental group can be attributed to the explicit instruction carried out by L1 use. By the same token, Ortega (2014) highlighted that especially skill acquisition theorists support securing declarative information so that it will be transformed into procedural information. As for cognitive theories, they vary while explaining L2 development. Emergentism, corpus linguistics and connectionist model of language are some of them (Ortega, 2014). Input Processing theory (VanPatten, 1996), based on Krashen's (1982) input hypothesis aims to attain richer intake from input by getting the learners involved in structured input activities. In line with this, L1 use can be stated to induce richer intake from input by enabling dual focus. Moreover, learning is a dynamic process having neural, cognitive, and linguistic dimensions as indicated by Pienemann (1998), and O'Grady (2003). Hence, the fact that easing cognitive load and dual focus can be possible through L1 use aligns with the skill theory and particularly with sociocultural theory (Vygotsky, 1978) due to its scaffolding role.

As for the contextual dimension, L1 use can be stated to have a contextual impact based upon the findings of the current study. In the similar vein, there are some second language acquisition researchers (Collentine \& Freed, 2004; Firth \& Wanger, 1997; Tarone, 2007) who focused on contextual factors. Almost five decades ago, Hymes (1972) noted that "the key to understanding language in context is to start not with language but with context ... [and then to] systematically relate the two" (pp. xix-lvii). Moreover, labelling learning contexts through such dichotomous terms as natural(istic) vs. classroom or educational contexts, or as second language vs. foreign language contexts (Bardovi-Harlig \& Dörnyei, 1998; VanPatten \& Lee, 1990) neglects the tremendous variation which is present in each context with respect to the characteristics of learning opportunities and outcomes (Housen et al., 2011). Given these, the stress-free and biculturally laden context can be stated to arise within the environment of this study.

As far as the interactional dimension is concerned, it is possible to indicate that L1 use facilitates interaction, enabling better learning. Accordingly, interactions can be said to serve as a major source of language data, enhancing the learning process. By participating in L2 interactions, learners gain access to conditions, some of which are processing comprehensible input (Krashen, 1981), interactional restructuring with focus on form (Long, 1998) and production of modified output (Swain, 1985) so as to bolster language learning. In this regard, Long's interaction hypothesis (1996) built up work by Hatch (1978) as well as the one by Krashen (1981). Long posits that interaction has a facilitative role for acquisition. In this regard, unobstructed communication induced by L1 use enables the interaction to take place. Further, negotiation, which is one type of interaction, termed by Long, Pica, and others, allows non-native speakers and their interlocutors to indicate that they do not comprehend something (Gass \& Varonis, 1994; Pica, 1994). In line with this, L1 use led the learners to be inquiry-oriented instead of shying away from talking in L2. Learners get opportunities to comprehend and utilize the language which is incomprehensible through negotiation and taking advantage of L1 use. Furthermore, the learners get more input and have more chances for output (Swain, 1985).

\section{Conclusions}

The present study indicates that L1 use has positive effect on boosting speaking skill in L2 of low intermediate and high intermediate students. Judicious and systematic L1 use in FL contexts yielded better scores in terms of improving speaking skill in L2 in comparison to only L2 approach. These results align with the point by many scholars (Atkinson, 1987; Cook, 2001; Galali \& Cinkara, 2017; Pavon 
Vázquez \& Ramos Ordóñez, 2018; Swain \& Lapkin, 2000) that L1 should only be utilized to help construct knowledge in L2, make interpersonal interactions easier and also augment efficiency. This study also acknowledges the constraints of only L2 instruction and language separation (Goodwin, 2017). It is possible state that $\mathrm{L} 1$ is a precious resource and advantageous as an instrumental in the classroom in that it conveys and clarifies meaning and encourages learning in cooperation. In this regard, one of the pedagogical recommendations stemming from this study is that teachers might consider using the L1 in order to scaffold the students while constructing meaning in a judicious manner by which students will not be deprived of being exposed to the L2 (Lo, 2015). The findings presented in this study are hoped to raise awareness with respect to re-thinking of the effect of L1 use in the instruction and learning of L2 education environments.

However, the caveats of the present study are that it was carried out with the students whose academic success is high and it included students whose age range is between 14 and 17. Finally, further research might investigate the presence of the L1 in FL contexts with students and teachers in various contexts by employing different pedagogies such as translanguaging. Also, further research might replicate the current study about the L1 use in FL contexts across many other schools with similar students whose academic success is as high.

\section{Ethics Committee Approval}

The author(s) confirm(s) that the study does not need ethics committee approval according to the research integrity rules in their country. (Date of Confirmation: January 23, 2020)

\section{References}

Anderson, N. J. (1991). Individual differences in strategy use in second language reading and testing. The Modern Language Journal, 75(4), 460-472.

Atkinson, D. (1987). The mother tongue in the classroom: A neglected resource?. ELT journal, 41(4), 241-247.

Atkinson, D. (1993). Teaching monolingual classes (Vol. 12). London: Longman.

Antón, M., \& DiCamilla, F. (1998). Socio-cognitive functions of L1 collaborative interaction in the L2 classroom. Canadian modern language review, 54(3), 314-342.

Bardovi-Harlig, K., \& Dörnyei, Z. (1998). Do language learners recognize pragmatic violations? Pragmatic versus grammatical awareness in instructed L2 learning. Tesol Quarterly, 32(2), 233-259.

Benson, C. (2002). Transfer/Cross-linguistic influence. ELT journal, 56(1), 68-70.

Bergsleighner, J. M. (2002). Grammar and interaction in the EFL classroom: A sociocultural study. (Unpublished doctoral dissertation). Universidade Federal de Santa Catarina, Florianópolis.

Block, E. (1986). The comprehension strategies of second language readers. Tesol Quarterly, 20(3), 463-494.

Brooks, F. B., \& Donato, R. (1994). Vygotskyan approaches to understanding foreign language learner discourse during communicative tasks. Hispania,77, 262-274.

Bruner, J. S. (1983). Child's talk: Learning to use Language. New York. 
Butzkamm, W., \& Caldwell, J. A. (2009). The bilingual reform: A paradigm shift in foreign language teaching. Narr Francke Attempto Verlag

Carson, E., \& Kashihara, H. (2012). Using the L1 in the L2 classroom: The students speak. The Language Teacher, 36(4), 41-48.

Çelik, Ş. S., \& Aydin, S. (2018). A review of research on the use of native language in EFL classes. Literacy, 4(2), 1-14.

Chang, C. Y. (2009). Teacher's use of students' L1 in an EFL classroom. (Unpublished master's thesis). National Cheung Kang University, Taiwan.

Cipriani, F. (2001). Oral participation strategies in the foreign language classrooms: an ethnographic account (Unpublished doctoral dissertation). Universidade Federal de Santa Catarina, Florianópolis.

Collentine, J., \& Freed, B. F. (2004). Learning context and its effects on second language acquisition: Introduction. Studies in second language acquisition, 26(2), 153-171.

Collins, K. M. T., Onwuegbuzie, A. J., \& Sutton, I. L. (2006). A model incorporating the rationale and purpose for conducting mixed methods research in special education and beyond. Learning Disabilities: A Contemporary Journal, 4(1), 67-100.

Cook, V. (2001). Using the First Language in the Classroom. The Canadian Modern Language Review/La Revue candienne des langues vivantes, 57(3), 402-423.

Cook, G. (2010). Translation in language teaching: An argument for reassessment. Oxford University Press.

Dörnyei, Z. (2007). Research methods in applied linguistics: Quantitative, qualitative, and mixed methodologies: Oxford University Press Oxford.

Edstrom, A. (2006). L1 use in the L2 classroom: One teacher's self-evaluation. Canadian Modern Language Review, 63(2), 275-292.

Ellis, R. (1994). The study of second language acquisition. Oxford, England: Oxford University Press.

Ferguson, G. (2003). Classroom code-switching in post-colonial contexts: Functions, attitudes and policies. AILA Review, 16(1), 38-51.

Firth, A., \& Wagner, J. (1997). On discourse, communication, and (some) fundamental concepts in SLA research. The Modern Language Journal, 81(3), 285-300.

Galali, A., \& Cinkara, E. (2017). The Use of L1 in English as a Foreign Language Classes: Insights from Iraqi Tertiary Level Students. Advances in Language and Literary Studies, 8(5), 54-64.

Gass, S. M., \& Varonis, E. M. (1994). Input, interaction, and second language production. Studies in Second Language Acquisition, 16(3), 283-302.

Goodwin, A. L. (2017). Who is in the classroom now? Teacher preparation and the education of immigrant children. Educational Studies, 53(5), 433-449.

Grim, F. (2010). L1 in the L2 Classroom at the Secondary and College Levels: A Comparison of Functions and Use by Teachers. Electronic Journal of Foreign Language Teaching, 7(2), 193-209.

Hall, G., \& Cook, G. (2014). Own language use in ELT: exploring global practices and attitudes. Language Issues: The ESOL Journal, 25(1), 35-43.

Hatch, E. (1978). Acquisition of syntax in a second language. In J. Richards (Eds.), Understanding second and foreign language learning, (pp.34-70). Rowley, MA: Newbury House. 
Housen, A., Schoonjans, E., Janssens, S., Welcomme, A., Schoonheere, E., \& Pierrard, M. (2011). Conceptualizing and measuring the impact of contextual factors in instructed SLA-the role of language prominence. IRAL-International Review of Applied Linguistics in Language Teaching, 49(2), 83-112.

Howatt, A. P. R., \& Widdowson, H. G. (2004). A history of ELT. Oxford University Press.

Hymes, D. (1972). On Communicative Competence. In J. Pride, \& J. Holmes, Sociolinguistics. Selected Readings. (pp. 269-293). Harmondsworth: Penguin.

Johnson, R. B., Onwuegbuzie, A. J., \& Turner, L. A. (2007). Toward a definition of mixed methods research. Journal of mixed methods research, 1(2), 112-133.

Kaplan, R. B. (1966). Cultural thought patterns in intercultural education. Language Learning, 16(1-2), $1-20$.

Kelly, N., \& Bruen, J. (2015). Translation as a pedagogical tool in the foreign language classroom: A qualitative study of attitudes and behaviours. Language Teaching Research, 19(2), 150-168.

Kern, R. G. (1994). The role of mental translation in second language reading. Studies in Second Language Acquisition, 16(4), 441-461.

Kondracki, N. L., \& Wellman, N. S. (2002). Content analysis: Review of methods and their applications in nutrition education. Journal of Nutrition Education and Behavior, 34(4), 224-230

Kovačić, A., \& Kirinić, V. (2011). To Use or Not to Use: First Language in Tertiary Instruction of English as a Foreign Language. In Sarajevo: The First International Conference on Foreign Language Teaching and Applied Linguistics, Sarajevo.

Krashen, S.D. (1981). Second language acquisition and second language learning. University of Southern California.

Krashen, S.D. (1982). Principles and Practice in Second Language Acquisition. Oxford: Pergamon.

Lee, J. H. (2016). Exploring non-native English-speaking teachers' beliefs about the monolingual approach: Differences between pre-service and in-service Korean teachers of English. Journal of Multilingual and Multicultural Development, 37(8), 759-773.

Littlewood, W. \& Yu, B. (2009). First language and target language in the foreign language classroom. Language Teaching, 44(1), 64-77.

Lo, Y. Y. (2015). How much L1 is too much? Teachers' language use in response to students' abilities and classroom interaction in Content and Language Integrated Learning. International Journal of Bilingual Education and Bilingualism, 18(3), 270-288.

Long, M. (1996). The role of the linguistic environment in second language acquisition. Handbook of second language acquisition. San Diego, CA: Academic.

Macaro, E. (2001). Analysing student teachers' codeswitching in foreign language classrooms: Theories and decision making. The Modern Language Journal, 85(4), 531-548.

Mahmoudi, L., \& Amirkhiz, S. Y. Y. (2011). The Use of Persian in the EFL Classroom--The Case of English Teaching and Learning at Pre-University Level in Iran. English Language Teaching, 4(1), 135-140.

Mohebbi, H., \& Alavi, S. M. (2014). Teachers' first language use in second language learning classroom context: A Questionnaire-based study. Bellaterra: Journal of Teaching and Learning Language and Literature, 7(4), 57-73. 
Nation, P. (2003). The role of the first language in foreign language learning. Asian EFL journal, 5(2), $1-8$.

Norman, J. (2008). Benefits and drawbacks to L1 use in the L2 classroom. In K. Bradford Watts, T. Muller, \& M. Swanson (Eds.), JALT2007 Conference Proceedings. Tokyo: JALT.

O'Grady, W. (2003). The radical middle: Nativism without universal grammar. In C. Doughty \& M. H.Long (Eds.), Handbook of second language acquisition, (pp.43-62). Oxford, UK: Blackwell.

O'Malley, J. M. \& Chamot, A. U. (1990). Learning strategies in second language acquisition. Cambridge university press.

Ortega, L. (2014). Understanding second language acquisition. Routledge.

Park, E. S. (2013). Learner-generated noticing behavior by novice learners: Tracing the effects of learners' L1 on their emerging L2. Applied linguistics, 34(1), 74-98.

Patton, M. Q. (2002). Qualitative research and evaluation methods. Thousand Oaks. Cal.: Sage Publications.

Pavón Vázquez, V., \& Ramos Ordóñez, M. D. C. (2019). Describing the use of the L1 in CLIL: an analysis of L1 communication strategies in classroom interaction. International Journal of Bilingual Education and Bilingualism, 22(1), 35-48.

Pica, T. (1994). Research on negotiation: What does it reveal about second-language learning conditions, processes, and outcomes?. Language learning, 44(3), 493-527.

Pienemann, M. (1998). Language processing and second language development: Processability theory (Vol. 15). John Benjamins Publishing.

Qi, D. S. (1998). An inquiry into language-switching in second language composing processes. The Canadian Modern Language Review, 54(3), 413-435.

Richards, J. C., \& Rodgers, T. S. (2014). Approaches and methods in language teaching. Cambridge university press.

Russell, J., \& Spada, N. (2006). The effectiveness of corrective feedback for the acquisition of L2 grammar. Synthesizing research on language learning and teaching, 13, 133-164.

Sali, P. (2014). An analysis of the teachers' use of L1 in Turkish EFL classrooms. System, 42, 308-318.

Sampson, A. (2012). Learner code-switching versus English only. ELT journal, 66(3), 293-303.

Savignon, S. J. (1983). Communicative Competence: Theory and Classroom Practice. Canadian Modern Language Review, 40(3), 464-465

Scott, V. M., \& FUENTE, M. J. D. L. (2008). What's the problem? L2 learners' use of the L1 during consciousness-raising, form-focused tasks. The Modern Language Journal, 92(1), 100-113.

Shamash, Y. (1990). Learning in translation: Beyond language experience in ESL. Voices, 2(2), 71-75.

Shouyuan, W., \& Xingwei, M. (2003). The theory and methods of English listening teaching. Media in Foreign Language Instruction, 4, 1-5.

Storch, N., \& Wigglesworth, G. (2003). Is there a role for use of the L1 in L2 setting? TESOL quarterly, 37(4), 760-770.

Swain, M. (1985). Communicative competence: Some roles of comprehensible input and comprehensible output in its development. Input in second language acquisition, 15, 165-179. 
Swain, M., \& Lapkin, S. (2000). Task-based second language learning: The uses of the first language. Language Teaching Research, 4(3), 251-274.

Tarone, E. (2007). Sociolinguistic approaches to second language acquisition research. The Modern Language Journal, 91, 837-848.

Thalheimer, W., \& Cook, S. (2002). How to calculate effect sizes from published research: A simplified methodology. Work-Learning Research, 1, 1-9.

Timor, T. (2012). Use of the mother tongue in teaching a foreign language. Language Education in Asia, $3(1), 7-17$.

Timuçin, M., \& Baytar, İ. (2015). The functions of the use of L1: Insights from an EFL classroom. Kastamonu Education Journal, 23(1), 241-252.

Thompson, G. L. (2006). Teacher and student first language and target language use in the foreign language classroom: a qualitative and quantitative study of language choice (Unpublished doctoral dissertation). University of Arizona, Arizona, USA

Tucker, G. R. (1999). A global perspective on bilingualism and bilingual education. Washington, DC: ERIC Clearinghouse on Languages and Linguistics.

Turnbull, M. (2001). There is a role for the L1 in second and foreign teaching, but .... The Canadian Modern Language Review, 57(4), 531-538.

Turnbull, M., \& Arnett, K. (2002). Teachers' uses of the target and first languages in second and foreign language classroom. Annual Review of Applied Linguistics, 22, 204-218.

Turnbull, M., \& Dailey-O'Cain, J. (2009). Concluding reflections: Moving forward. First language use in second and foreign language learning, 182-186.

Upton, T. A. (1997). First and second language use in reading comprehension strategies of Japanese ESL students. TESL-EJ, 3(1).

Uzawa, K., \& Cumming, A. (1989). Writing strategies in Japanese as a foreign language: Lowering or keeping up the standards. Canadian Modern Language Review, 46(1), 178-194.

VanPatten, B. (1996). Input processing and grammar instruction in second language acquisition. Greenwood Publishing Group.

VanPatten, B., \& Lee, J. F. (1990). Second language acquisition/foreign language learning (No. 58). Multilingual Matters Ltd.

Vygotsky, L. S. (1978). Mind in society: The development of higher psychological processes. Cambridge, MA: Harvard University Press.

Wach, A., \& Monroy, F. (2019). Beliefs about L1 use in teaching English: A comparative study of Polish and Spanish teacher-trainees. Language Teaching Research, 1362168819830422.

Wang, W., \& Wen, Q. (2002). L1 use in the L2 composing process: An exploratory study of 16 Chinese EFL writers. Journal of second language writing, 11(3), 225-246.

Weschler, R. (1997). Uses of Japanese in the English Classroom: Introducing the Functional-Translation Method. Kyoritsu Women's University Department of International Studies Journal, 12, 87-110.

Yenice, Z. E. (2018). The Use of L1 in EFL Classrooms in the Context of Turkey. Uludağ University, Bursa, Turkey. 
Yu, S. (2016). An Exploratory Study on the Role of L1 Use in Peer Written Feedback of L2 Writing. Porta Linguarum, 25,135-146.

\section{Appendix A.}

1. Did you enjoy the lessons in which L1 was used? Why/Why not?

2. What are the main factors leading to your success in L2 (English) speaking skill? How?

3. What features of L1 use did you find helpful for your second language anxiety?

\section{Birinci dil kullanımının ikinci dilde konuşma becerisini geliştirme açısından farklı dil yetkinlik düzeylerindeki etkinliği}

\section{$\ddot{O} z$}

Bu çalışma, birinci dil kullanımının İngilizce yi yabancı dil olarak öğrenenlerin ikinci dil konuşma becerilerine etkisini ve öğrencilerin ikinci dil konuşma becerisini geliştirme açısından birinci dil kullanımına dair algılarını inceler. Çalı̧̧ma,Türkiye'de bir Fen Lisesinde 60 alt-orta ve 60 üst-orta İngilizce yeterlilik düzeyindeki öğrenciler ile 10 haftalık sürede gerçekleştirilmiştir. Her bir yeterlilik düzeyinde öğrencilerin yarısı deney, diğer yarısı kontrol grubu olarak belirlenmiştir. Her bir düzeydeki deney grupları, 10 haftalık sürede (40 ders saati) ikinci dilde konuşma becerisini geliştirmek için birinci dil kullanımına maruz bırakılmışıı. Ancak kontrol grupları, iletişimsel yaklaşım ile eğitim görmüştür. Bu çalışmada açıklayıcı ardışık karışık yöntem tasarımı kullanılmışırı. Bağımlı örneklem t-testi analizi, birinci dil kullanımının öğrencilerin ikinci dil becerilerini geliştirmede önemli bir rol oynadığını göstermiş̧tir.Yarı yapılandırılmış görüşmeler, öğrencilerin ikinci dilde konuşma becerisini geliştirmek için birinci dil kullanımına bilişsel yükü hafifletmesi, stressiz bir ortam sunması dolayısıyla olumlu yaklaştığını ortaya koymuştur. Son olarak, yapılandırılmış ve sistematik birinci dil kullanımına maruz kalan öğrenciler, ikinci dilde konuşma becerisini geliştirme ve ikinci dile karşı olumlu bir algı oluşturma bakımından sadece ikinci dile maruz kalan öğrencilerinden daha iyi bir performans sergilemiştir. Pedagojik çıkarımlar irdelenmiştir.

Anahtar sözcükler: birinci dil kullanımı; ikinci dilde sözel ifade; öğrencilerin ikinci dil algısı

\section{AUTHOR BIODATA}

Muhammet Yaşar Yüzlü is currently pursuing his Ph.D in ELT at Bahçeşehir University (BAU).He has been working as an English teacher at Ministry of National Education in Turkey since 2003. His research interests include bilingualism, translanguaging, teacher identity and teacher education.

Prof. Dr. Derin Atay has been working at Bahçeşehir University (BAU) in the Department of Foreign Language Education. She also has been working as the Dean of Faculty of Educational Sciences since August 2019. Her research interests include teacher research, culture in language education, pre-service and in-service teacher education, $21^{\text {st }}$ century skills and especially critical thinking in language education. 